\title{
2. Da criação ao fim do Proálcool
}

\section{4 de novembro de 1975: o governo brasileiro cria o Proálcool}

O recém-empossado presidente Ernesto Geisel, ex-presidente da Petrobras, tomou uma série de medidas na área do álcool e, em 14 de novembro de 1975, por meio do Decreto n. 76.593, o governo brasileiro criou o Programa Nacional do Álcool (Proálcool) (Menezes, 1980).

Muitos foram aqueles que, com entusiasmo, defendiam o uso automotivo do álcool de cana-de-açúcar. Entre os mais conhecidos estavam José Walter Bautista Vidal ${ }^{1}$ (Figura 10), Lamartine Navarro Júnior, Luiz Gonzaga Bertelli, Tobias J. Barretto de Menezes, Cícero Junqueira Franco, Expedito José de Sá Parente, Ozires Silva (ex-presidente da Embraer, presidente da Petrobras de 1986 a 1988 e ministro da Infraestrutura de 1990 a 1991), Severo Fagundes Gomes (ministro da Indústria e Comércio de 1974 a 1977), João Camilo Penna (ministro da Indústria e Comércio de 1979 a 1984) e Antonio Dias Leite Júnior (ministro de Minas e Energia de 1969 a 1974).

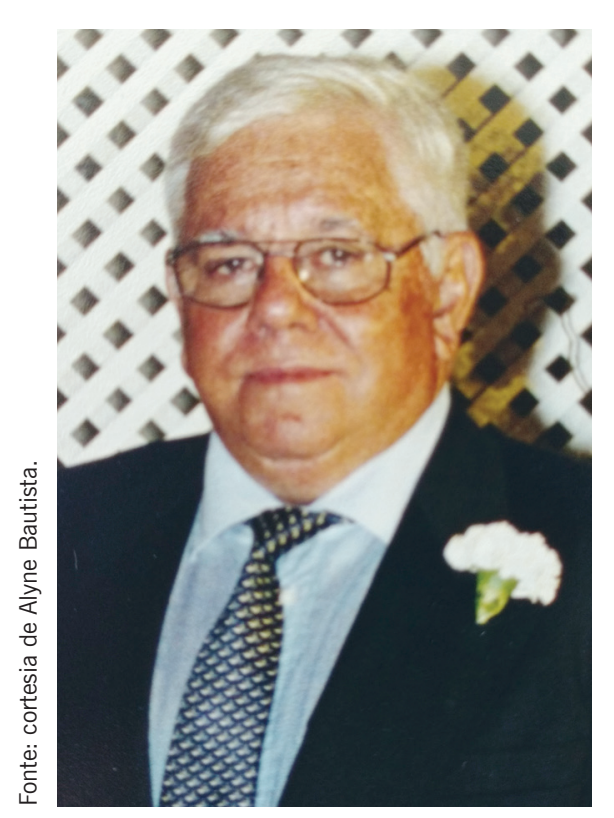

Figura 10: José Walter Bautista Vidal.

1 Bautista Vidal, um dos pioneiros no Proálcool, tinha como característica uma defesa do Proálcool mais aguerrida. Em seu livro Brasil, civilização suicida mostra mais claramente suas ideias. 


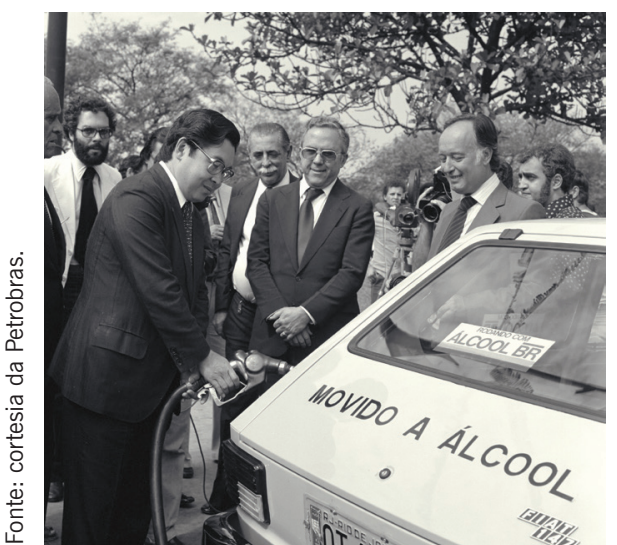

Figura 11: Ministro Shigeaki Ueki abastece um carro a álcool.

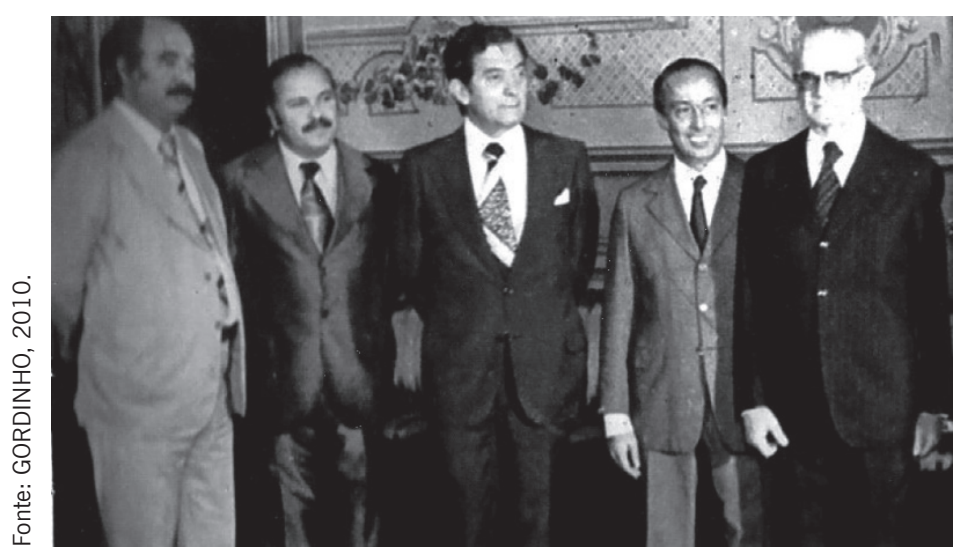

Figura 12: Fernando dos Reis, Lair Antonio de Souza, Maurílio Biagi e Lamartine Navarro Júnior com o Presidente Geisel em 1974.

Lamartine Navarro Júnior propôs a criação do Proálcool ao apresentar o estudo Fotossintese como fonte energética (1974). Os engenheiros Cicero Junqueira Franco e Mircea Manolescu participaram do estudo, que foi encaminhado ao presidente do Conselho Nacional do Petróleo (CNP), Araken de Oliveira, sugerindo que incentivos fossem criados para a produção de etanol diretamente da cana-de-açúcar. Este estudo é considerado o marco inicial de proposição do Proálcool ${ }^{2}$. A oportunidade de ampliar o uso de etanol combustível para substituir a gasolina automotiva foi identificada por Navarro Júnior como forma de liberar correntes de refino de petróleo para a produção de nafta petroquímica. Recentemente ${ }^{3}$, a Associação Brasileira da Indústria Química (Abiquim) comunicou ao mercado que "nos últimos anos, a Petrobras tomou uma decisão unilateral de desviar a nafta petroquímica para cobrir o seu déficit de produção de gasolina, importando a matéria-prima (nafta) para atender o setor industrial", o que indica estar ainda viva a relação entre o etanol, a gasolina e a nafta petroquímica utilizada como matéria-prima pelo setor petroquímico.

Naquele momento, havia preocupação em relação ao preço do "novo produto" (álcool) e sua relação com o preço do açúcar. Segundo Goldemberg (2011), o preço do etanol foi estabelecido em paridade com o preço

2 Conforme <www.jornalcana.com.br/lamartine-navarro-jr-foi-um-dos-mentores-do-proalcool/.

3 Comunicação ao mercado publicada em jornais de grande circulação (O Estado de S. Paulo, Folha de S. Paulo, Valor Econômico) pela Abiquim, em 29 out. 2015. 
do açúcar, devendo ser 35\% superior ao preço de 1 quilo de açúcar. Essa relação de preços iria influenciar o mix $x^{4}$ para o açúcar e álcool produzidos nas usinas. O cálculo da relação de paridade entre o etanol e a gasolina foi formulado pelo engenheiro Cicero Junqueira Franco ${ }^{5}$.

Assim, o Brasil conquistou a liderança mundial na produção e no uso de etanol de cana-de-açúcar graças a uma combinação bem-sucedida de ações de longo prazo do governo e da iniciativa privada, particularmente no que se refere à pesquisa agronômica. Quando o Proálcool foi implementado, o Brasil já era um relevante produtor de cana-de-açúcar, moendo 68,3 milhões de toneladas de cana (tc)/ano e produzindo 5,9 milhões de toneladas de açúcar, embora a produção de etanol combustível fosse ainda modesta, de 555,6 milhões de litros, dos quais 232,6 milhões de litros de etanol anidro e 323,0 milhões de litros de etanol hidratado (Nastari, 1983).

Na primeira fase do Proálcool (1975-1979), o álcool produzido em destilarias anexas às usinas de açúcar era do tipo "anidro", ou seja, desidratado, o que permitia a mistura com a gasolina. A produção de álcool cresceu de 600 milhões de litros por ano em 1975-1976 para 3,4 bilhões de litros por ano em 1979-1980.

\section{Maior incentivo às pesquisas agronômicas de cana-de-açúcar}

Até 1975, a cultura da cana-de-açúcar no Brasil dependia de poucas variedades, predominando na região Centro-Sul a variedade NA567916 ${ }^{6}$ selecionada no norte da Argentina. Com o Planalsucar, foram formados pesquisadores para cada estação experimental e foi criado um banco de germoplasma em Alagoas. Novos grupos de pesquisa em solos, herbicidas, controle biológico de pragas da cana e doenças foram constituídos.

Na era pré-Proálcool, os principais centros de pesquisa a trabalhar com a cana-de-açúcar eram do Instituto Agronômico de Campinas (IAC), sendo seu programa de melhoramento (iniciado em 1933) e os projetos com foco em fitotecnia (áreas de nutrição e adubação, espaçamento etc.) desenvolvidos nas estações experimentais de Piracicaba e Ribeirão Preto (SP), hoje Centro Cana IAC, e o programa

\footnotetext{
Designação que se usa para a proporção da cana utilizada na produção de açúcar ou de álcool. Informação prestada por Plinio Nastari, 2015.

Variedade NA (Norte-Argentina) produzida em Chacra Experimental em Salta, Argentina.
} 
de seleção desenvolvido na estação experimental de Campos (RJ), pertencente ao IAA. Posteriormente, já na década de 1970, o Planalsucar, criado no início dos anos 1970, incorporou a pesquisa realizada em Campos à sua rede de estações experimentais em todo o Brasil, criando um robusto programa de melhoramento de cana-de-açúcar (Figura 13).

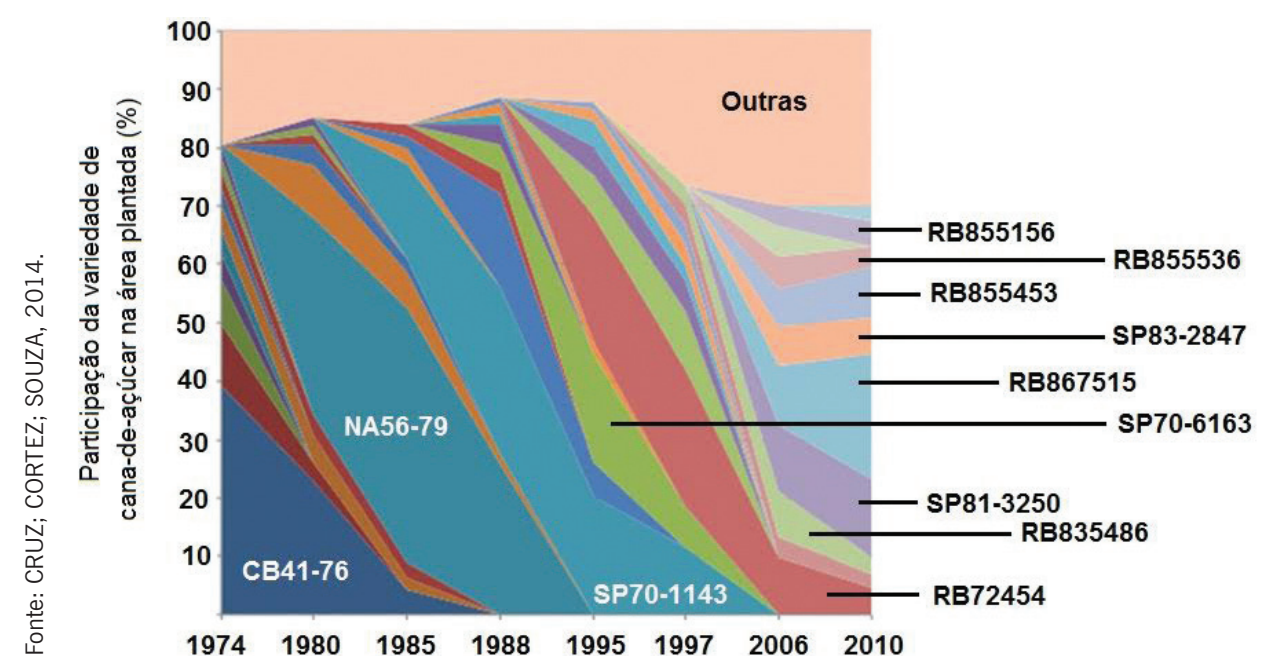

Figura 13: Uso crescente de variedades comerciais de cana-de-açúcar de 1974 a 2010 no Brasil.

\section{Década de 1970}

\section{Ação estratégica no Instituto de Pesquisas Tecnológicas (IPT) do estado de São Paulo para colaboração no desenvolvimento do Proálcool}

Para alinhar as competências em pesquisa tecnológica do IPT, até então organizadas por modalidades de engenharia, com o esforço nacional focado em segurança energética, o superintendente do IPT, Alberto Pereira de Castro, criou o Programa de Energia como uma ação estratégica transversal objetivando coordenar e incentivar projetos nas divisões técnicas do IPT. O referido programa, que arregimentava pesquisadores nas divisões, recebia pelo lado externo apoio da Comissão Nacional de Energia (CNE), cujo secretário executivo, Eduardo Celestino Rodrigues, coordenava as ações nacionais voltadas à segurança 
energética. Assim, inúmeros projetos foram desenvolvidos pelas divisões técnicas, com suporte financeiro de diversos órgãos estaduais e federais, sob a coordenação do Programa de Energia. São exemplos:

- Projeto e construção de miniusina de etanol (1978/1979, Divisão de Engenharia Química, com suporte Secretaria de Indústria, Comércio, Ciência e Tecnologia do Governo do Estado de São Paulo, $\mathrm{SICCT/SP).}$

- Reestabelecimento da competência do IPT na área de motores (1977, Divisão de Engenharia Mecânica, com a contratação de Nedo Eston de Eston e apoio da SICCT/SP e Companhia Energética de São Paulo, CESP).

- Conservação de energia na indústria (1978, Divisão de Engenharia Mecânica/Agrupamento de Engenharia Térmica, com suporte da Comissão Nacional de Energia, CNE; Ministério de Minas e Energia, MME e Financiadora de Estudos e Projetos, FINEP).

- Corrosão do etanol (1978, Divisão de Metalurgia, com pesquisadores Stephan Wolinec e Deniol Tanaka e suporte da SICCT/SP).

- Potencial de biomassas no estado (1978/1979, Divisão de Engenharia de Sistemas, com pesquisador Hélio Mattar e suporte da CESP).

Com a criação do Laboratório de Motores, instalação de bancadas dinamométricas e de equipamentos para a análise de combustíveis, cresceu a participação do IPT junto aos setores privado e governamental voltada à utilização de combustíveis alternativos. Para mencionar alguns projetos ligados ao uso veicular de álcoois nesse período inicial:

- Centro de Apoio Tecnológico CAT/IPT, 1977 a 1980: projeto suportado pela Secretaria de Tecnologia Industrial (STI) do Ministério da Indústria e Comércio (MIC) a fim de disseminar tecnologia de motores a álcool para retíficas de motores, que convertiam motores de gasolina para Álcool Etílico Hidratado Carburante (AEHC), o que possibilitou que frotas de empresas estatais demonstrassem a viabilidade do uso do etanol para a população (Castro et al., 1982).

- Início de parceria com a CESP, 1978 a 1980: voltada à pesquisa do uso de metanol em motores diesel, principalmente de locomotivas, via nebulização desse álcool no coletor de admissão ou sua injeção 
na câmara misturado a aditivo promovedor de ignição. Essas mesmas tecnologias foram aplicadas no início da década de 1980 na utilização de etanol em motores diesel de porte veicular (Nigro, 1984).

Estudos desenvolvidos no final da década de 1970 e início da década de 1980, conjuntamente pelo IPT, Instituto Nacional de Tecnologia (INT) e a indústria automobilística sobre a compatibilidade de materiais com etanol, permitiram o desenvolvimento tecnológico nacional nesse campo e viabilizaram o uso de gasolina com altas concentrações de etanol, bem como dos carros a álcool e flex.

\section{7: primeira publicação sobre balanço energético do álcool}

Durante os anos 1970, incentivados pela crise energética, as instituições públicas e as entidades privadas realizaram muitas pesquisas em todas as áreas de energia. No II International Symposium on Alcohol Fuel Technology (ISAF), em Wolfsburg, na Alemanha, profissionais do Centro de Tecnologia Promon apresentaram o trabalho Energetics, Economics and Prospects of Fuel Alcohols in Brazil, no qual compararam o balanço de energia e os custos de etanol de cana e de mandioca (Vieira de Carvalho et al., 1977). José Goldemberg (Figura 14) publicou um trabalho na revista Science (Silva et al., 1978) que é considerado um marco bibliográfico sobre o Proálcool ("Energy Balance for Ethyl Alcohol Production from Crops") mostrando que o álcool, na verdade, é “energia solar líquida” (Figura 15).

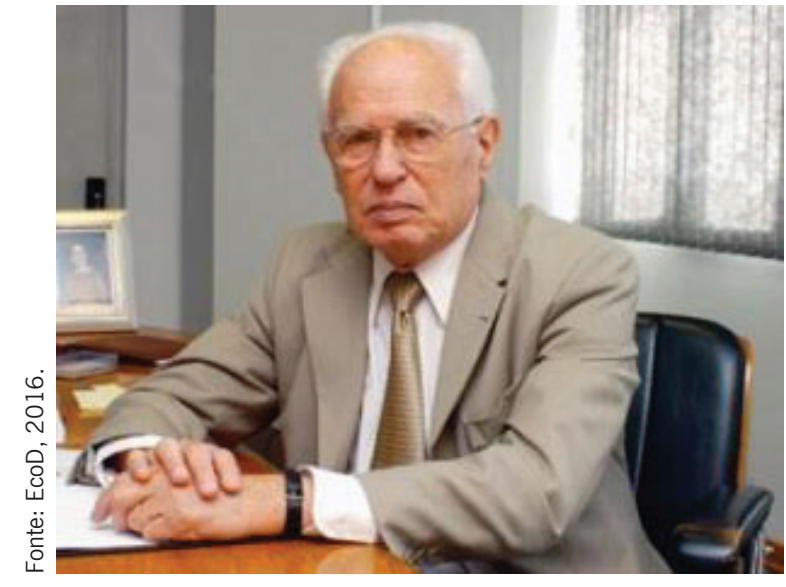

Figura 14: José Goldemberg.

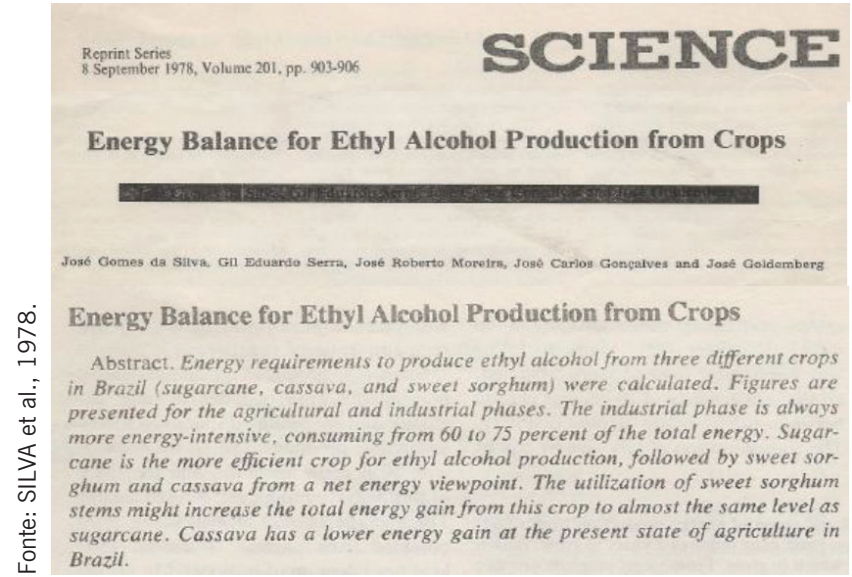

Figura 15: Artigo científico pioneiro tratando o balanço energético do etanol de cana-de-açúcar. 
Segundo Sergio C. Trindade, também do Centro de Tecnologia Promon, que na época incluía Arnaldo Vieira de Carvalho, Manoel Régis Lima Verde Leal, Victor Yang, Carlos Costa Ribeiro, Walter Vergara, entre outros, foram feitos trabalhos pioneiros relevantes para o Proálcool e suas ramificações, como: 1) análise da tecnologia do INT de álcool de mandioca;2) estudo multicliente sobre alternativas tecnológicas de processamento de vinhoto (vinhaça), conduzido por Costa Ribeiro; 3) novo processo de produção de etanol de mandioca no primeiro contrato de risco com a FINEP no Brasil; e 4) novo processo adiabático de produção de eteno de etanol, em parceria com Haldor Topsøe da Dinamarca (que é usado hoje pela Braskem e que foi anteriormente usado pela Petrobras na salgema em Alagoas).

\section{Desenvolvimento de motores (álcool e flex-fuel)}

Urbano Ernesto Stumpf (Figura 16), do ITA/CTA, desenvolveu na década de 1970 importantes estudos sobre o motor a álcool com dois objetivos essenciais: 1) tentativa de evitar os royalties pagos na fabricação dos motores importados e projetados no exterior; e 2) viabilizar o uso em grande escala de um combustível derivado da biomassa. Stumpf é considerado o pioneiro no desenvolvimento do motor a álcool brasileiro. Já Francisco Nigro, do IPT, e Henry Joseph Júnior, da Anfavea e Volkswagen, dentre outros, representam uma geração de engenheiros brasileiros que contribuíram para que o sonho de Stumpf se concretizasse. Posteriormente, junto com uma nova geração de engenheiros, como Fernando Damasceno, da Magneti Marelli, e Besaliel Botelho, da Bosch, contribuíram para que os motores flex-fuel se tornassem um enorme sucesso.

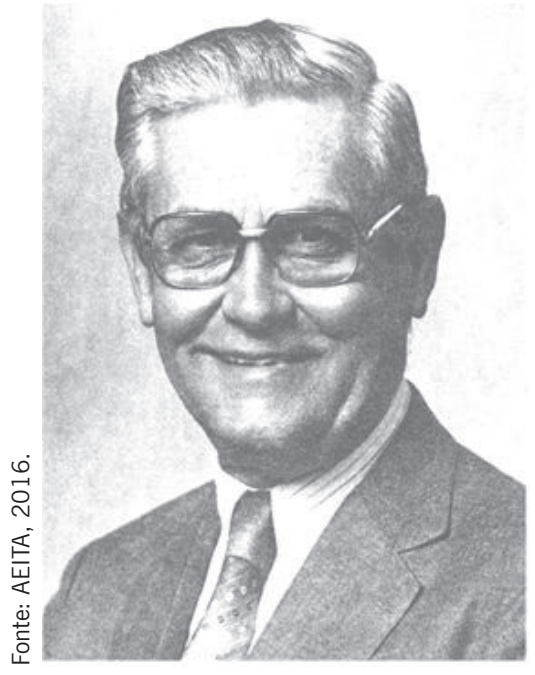

Figura 16: Urbano Ernesto Stumpf.

Embora o país tenha logrado importantes sucessos na viabilização do uso do etanol combustível, seja em mistura com a gasolina ou como combustível propriamente dito, existem ainda muitos desafios a vencer na área de motores, que deve passar por mudanças com o Inovar Auto, incluindo o aumento na eficiência do uso do etanol em relação à gasolina nos veículos flex com a entrada no mercado dos veículos híbridos. Esses temas estão bem tratados no livro publicado pelo BNDES Bioetanol de cana-de-açúcar, publicado em português, inglês, espanhol e francês (Figura 17). 


\section{8: criação da estação de hibridização de Camamu, Bahia, do Centro de Tecnologia Copersucar}

Já na iniciativa privada o Centro de Tecnologia Copersucar (CTC) cria, em 1969, a estação experimental de hibridização de Camamu, Bahia (Figura 18) ${ }^{7}$.

\section{Final da década de 1970: fermentação contínua e hidrólise}

\section{A fermentação contínua chega ao Brasil}

A Usina Vale do Rosário implantou um sistema de fermentação contínua com tecnologia adquirida da empresa austríaca Vogelbusch. $\mathrm{O}$ interesse se deveu à possibilidade de economizar dornas, reduzir a mão de obra devido à mais fácil otimização e ao menor consumo de antiespumantes, tudo contribuindo para a redução de custos. Segundo o vice-presidente da Vale do Rosário, Cícero Junqueira Franco, inicialmente o processo era feito com um sistema semicontínuo, sendo a primeira dorna por batelada e mais outras duas interligadas. Os resultados foram muito bons, e outras duas linhas foram montadas em meados dos anos 1980, com uma produção total de 1,2 milhão de litros de álcool por dia.

No entanto, devido aos maiores problemas de contaminação bacteriana e ao "choque" causado no levedo durante a alimentação do mosto, a fermentação contínua nunca chegou a ter rendimentos iguais aos alcançados por batelada, tendo sido desativada no final da década de 1990. Ainda assim, a iniciativa da Vale do Rosário não foi isolada. A fermentação contínua chegou a atingir 30\% das destilarias brasileiras entre 1989 e 1995. Segundo Amorim (2005),

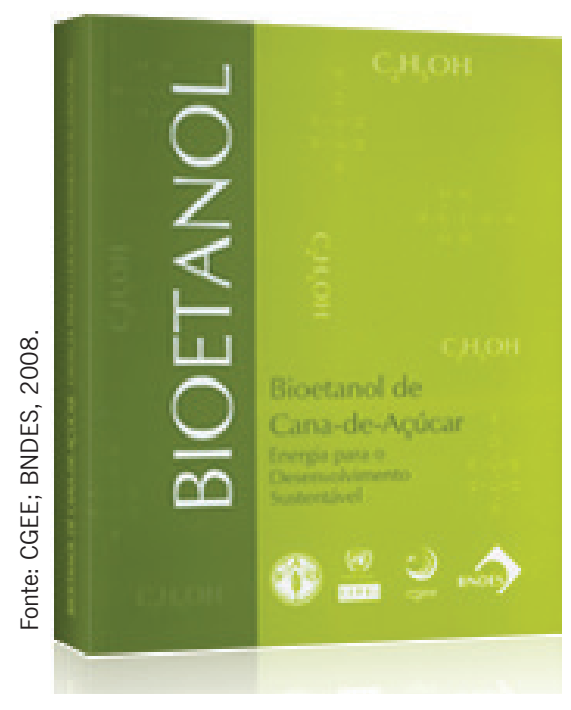

Figura 17: BNDES publica Bioetanol de Cana-de-Açúcar.

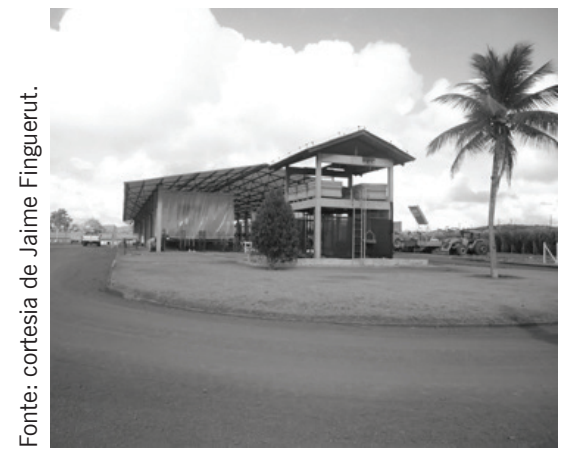

Figura 18: Estação experimental de Camamu, Bahia.

7 Conforme $<$ www.jornaldepiracicaba.com.br $>$. 
"há uma tendência generalizada do uso da fermentação por batelada no Brasil, principalmente pelo maior uso de melaço como matéria-prima, que faz aumentar a viscosidade e prejudica a concentração do levedo nas centrífugas". Ainda segundo Amorim, da Fermentec, o processo contínuo ainda precisa melhorar muito. Hoje, no Brasil, a fermentação contínua responde por cerca de 10\% do total. Nos EUA, também prevalece a fermentação por batelada.

\section{Início das pesquisas com hidrólise}

A história das pesquisas em hidrólise no Brasil nos remete, inicialmente, aos trabalhos de José Carlos Campana Gerez (Figura 19), da Companhia de Desenvolvimento Tecnológico (Codetec) $)^{8}$ da Unicamp, no final da década de 1970, quando o pesquisador desenvolveu estudos em hidrólise ácida. Esses trabalhos chegaram a ter uma planta-piloto montada no campus da Unicamp, mas o projeto foi descontinuado em função da falta de recursos a partir do início da década do 1980.

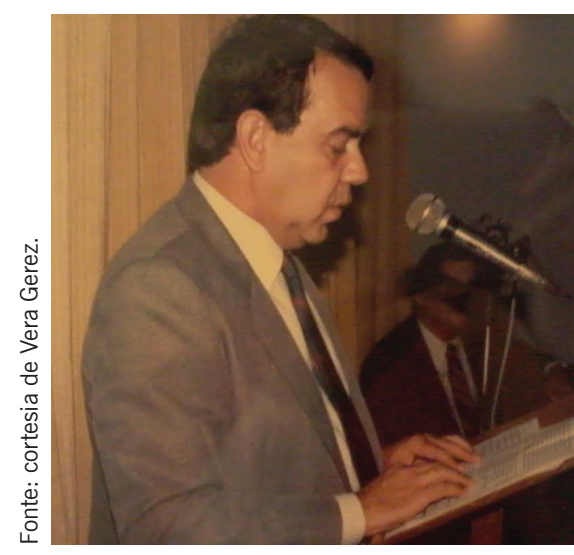

Figura 19: José Carlos Campana Gerez.

Ainda no final da década de 1970, por iniciativa do governo federal, para aproveitar saldos comerciais com a União Soviética foi criada a empresa Coalbra, cujo objetivo era usar uma tecnologia de hidrólise ácida trazida da antiga União Soviética para converter celulose em etanol e, como subproduto, ração animal (proteína de levedura). Esse projeto foi coordenado por Sérgio Motta e José Goldemberg e teve a colaboração de Gil Eduardo Serra e José Roberto Moreira. No projeto, foi montada uma planta de demonstração de 30 mil litros/dia no Triângulo Mineiro. A planta da Coalbra apresentou problemas técnicos, uma vez que a lignina de eucalipto não era facilmente desumidificada pelo filtro prensa, enquanto dificultava a fermentação do hidrolisado, que só ocorria com a fração celulose, como já era previsto pela tecnologia importada ${ }^{9}$. Assim, o elevado investimento (materiais especiais e caros), o elevado custo de produção e a baixa valoração da lignina como combustível inviabilizaram, do ponto de vista econômico, a iniciativa.

Ver <http://ocs.ige.Unicamp.br/ojs/rbi/article/view/344>.

Conforme comunicação pessoal de José Moreira. 
Anteriormente, no final da década de 1970, por iniciativa da CESP, e com a orientação de Eduardo Sabino de Oliveira, foi construído um gaseificador elétrico piloto de madeira para a produção de gás de síntese a ser convertido em metanol. O processo funcionou nas instalações da CESP em Corumbataí (SP) até 1987, sob o gerenciamento de José Roberto Moreira, com a construção de vários gaseificadores, alguns de grande porte (20 toneladas de madeira/hora), mas foi descontinuado devido ao desinteresse da empresa de atuar fora do seu nicho de mercado.

\section{9: muitos acontecimentos}

\section{Proóleo e as patentes do biodiesel no Brasil}

Em 1978, na Unicamp desenvolvem-se estudos sobre a transesterificação de óleos vegetais. Foram desenvolvidos catalisadores orgânicos com elevada basicidade (guanidinas), tendo em vista que em outros países catalisadores inorgânicos eram os preferidos.

Ainda no final da década de 1970, Expedito Parente, na Universidade Federal do Ceará, trabalhou com métodos de obtenção de biodiesel e sua utilização em motores. Submeteu a primeira patente ao INPI em 1980, que foi concedida em 1983.

Em 1979, o vice-presidente da República e presidente da Comissão Nacional de Energia, Aureliano Chaves, começou a articular o Proóleo (em analogia ao Proálcool) para a substituição do óleo diesel por óleos vegetais. Nesse sentido, ressalte-se a ação da Comissão Nacional de Energia (CNE), quando, em 21 de outubro de 1981, por meio das resoluções CNE n. 06 e 07, recomendou a criação do Programa Nacional de Energia de Óleos Vegetais para fins carburantes.

Em 1980, a Volkswagen do Brasil cedeu um carro Passat, com motor diesel, para que o grupo de Ulf Schuchardt, da Unicamp, realizasse testes ${ }^{10}$ com diferentes misturas de diesel/biodiesel/etanol. Estes duraram alguns anos e permitiram algumas conclusões: a) o diesel não forma misturas estáveis com o etanol; b) o diesel pode ser misturado em qualquer proporção com o biodiesel; c) o biodiesel pode ser misturado com o etanol em baixa proporção; d) a mistura energeticamente mais eficiente é $80 \%$ diesel/20\% biodiesel; e) a mistura mais eficiente pode conter até $5 \%$ de etanol.

10 O biodiesel utilizado nesses testes foi fornecido pela empresa Miracema, de Campinas (SP). 
Em 1981, com o estabelecimento do Programa Nacional de Energia de Óleos Vegetais pela Comissão Nacional de Energia, a STI do MIC passou a coordenar o programa OVEG I, voltado para a formação de base tecnológica sobre o uso de óleos vegetais e seus derivados em motores, compreendendo tanto a realização de testes dinamométricos como de campo. Após uma série de ensaios dinamométricos com óleos vegetais in natura ou degomados em motores de injeção direta, realizados no IPT, decidiu-se por transesterificar os óleos vegetais, uma vez que os depósitos formados e a contaminação do óleo lubrificante inviabilizavam sua utilização direta. Após ensaios dinamométricos iniciais, o IPT passou a acompanhar testes de campo de veículos de vários fabricantes operando com éster etílico e metílico de soja (Brasil, 1985). Os testes de campo ocorreram em 1983, envolvendo mais de 1 milhão de quilômetros percorridos, e sua avaliação compreendeu também milhares de horas em dinamômetro (Relatório Executivo da Comissão Técnica fornecido por Francisco Nigro).

Em 1982 foi depositada a primeira patente mundial de um reator contínuo para a transesterificação de óleos vegetais pelo grupo de Ulf Schuchardt. Com a mudança do governo em 1985, as atividades para a implantação do Proóleo cessaram. Mesmo assim, foi dada sequência aos trabalhos de desenvolvimento de catalisadores heterogêneos de guanidina e sua utilização nas transformações de óleos vegetais. Em 1998, foi publicado um artigo de revisão sobre transesterificação de óleos vegetais no Journal of the Brazilian Chemical Society, que, até hoje, é o artigo mais citado dessa revista.

\section{Segundo choque do petróleo em decorrência da Guerra do Golfo Pérsico}

Em 1979, ocorre o segundo choque do petróleo em decorrência da Guerra do Golfo Pérsico entre Irã e Iraque. Os preços do petróleo voltam a aumentar significativamente, passando de 12,9 dólares/barril em 1978 para 30,5 dólares/barril em 1980, levando a uma nova deterioração das contas brasileiras, já bastante prejudicadas devido ao primeiro choque e ao crescente endividamento externo mantido pelo governo brasileiro. O segundo choque do petróleo viabilizou outras opções energéticas, como a exploração do petróleo da bacia de Campos e provocou um novo impulso do álcool combustível, visando alcançar a pretendida autossuficiência em petróleo.

Início da segunda fase do Proálcool

Na segunda fase do Proálcool (1979-1985), o álcool passou a ser produzido também em destilarias autônomas, dedicadas exclusivamente à produção de álcool, sem produção de açúcar. Nesta fase, dá-se início à produção 
de álcool hidratado, o que permitiria seu uso generalizado em carros a álcool ${ }^{11}$, enquanto nos anos anteriores somente operavam algumas frotas de demonstração com carros convertidos (Figura 20) ${ }^{12}$. A produção de álcool cresceu substancialmente no período, chegando a 11,8 bilhões de litros na safra de 1985-1986.
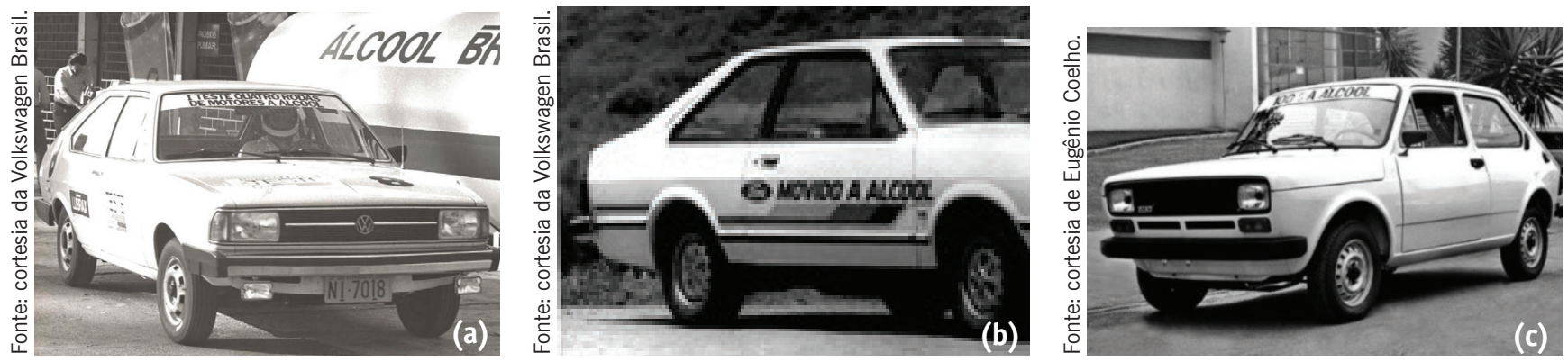

Figuras 20a, 20b e 20c: Em 1979, montadoras de veículos entraram num acordo com o governo brasileiro para a produção de veículos a álcool no Brasil (Gordinho, 2010).

Como a segunda fase do Proálcool foi de aumento de produção mais expressivo, investimentos maiores, tanto para a expansão da área plantada de cana como para a construção de novas destilarias, outros temas indiretamente associados ao programa, entraram em pauta. O governo federal, por meio da Comissão Executiva Nacional do Álcool (CENAL) produziu uma série de documentos tratando das questões mais relevantes, como "O Proálcool e as culturas alimentares" e outros de orientação.

Oportunidades foram criadas para o setor privado. Ressalte-se aqui a importância do modelo de avaliação de projetos usado pela CENAL e ao desenvolvimento de um parque de fornecedores nacionais, entre eles a Dedini e a Zanini, e de uma cadeia de indústrias metalúrgicas na região de Piracicaba, Sertãozinho, São Paulo e também em Pernambuco. Nomes como Dovílio Ometto e de antecessores como Mário Dedini fizeram parte dessa fase tão importante de consolidação da indústria sucroenergética no Brasil.

A maior parte dos recursos financeiros investidos tanto para a expansão da área de cana como para a implantação das usinas veio de empréstimos do governo federal, embora tenha havido o emprego

11 Houve, principalmente no período 1975-1979, uma certa resistência de algumas montadoras em aceitar a ideia do uso do álcool em seus motores devido à possibilidade de corrosão e também das mudanças necessárias devido às características diferentes do novo combustível (BNDES, 2008).

12 De acordo com Duquette (1989), em 1979 houve um acordo tripartite entre governo, montadoras e empresários do setor sucroalcooleiro que possibilitou a fabricação de carros a álcool no Brasil. 
de recursos vindos de órgãos externos, como o Banco Mundial, que concedeu dois empréstimos ao Proálcool para investimento, pesquisa e desenvolvimento, envolvendo FINEP e STI (World Bank, 1980).

Segundo Goldemberg (2008), com o início da venda do álcool hidratado nos postos de combustíveis, foi estabelecida, inicialmente, uma política de preços na qual o preço do álcool pago aos produtos deveria ser de 59\% do preço de venda da gasolina.

\section{A importância do papel inicial do CNPq e da FINEP}

Considerando as características de cada agência de fomento, o Conselho Nacional de Pesquisa (CNPq), promovendo a pesquisa no Brasil, e o Fundo Nacional de Estudos e Projetos (FINEP), mais dedicado ao financiamento de projetos com a participação da indústria, foram muito ativos no financiamento à pesquisa em bioenergia desde o início do Proálcool. O CNPq teve um papel fundamental no início do Proálcool com a publicação do livro Avaliação tecnológica do álcool etílico, em 1978, coordenado por Adolpho W. F. Anciães e que serviu para estabelecer o estado da arte no campo da produção de etanol. O CNPq atuou também de forma decisiva, oferecendo bolsas de pós-graduação dentro e fora do país em uma época em que os programas nacionais ainda não se encontravam totalmente desenvolvidos. Também relevante foi o papel da Coordenadoria de Aperfeiçoamento de Pessoal de Ensino Superior (CAPES), cujo oferecimento de bolsas colaborou para a sustentação do treinamento de pessoal na área.

\section{A importância do papel inicial da Secretaria de Tecnologia Industrial (STI) do Ministério da Indústria e do Comércio (MIC)}

O governo Figueiredo, em 1979, convidou José Israel Vargas (Figura 21) para a Secretaria da Tecnologia Industrial (STI) do MIC, sucedendo Bautista Vidal. O vice-presidente Aureliano Chaves e o então secretário Israel Vargas passaram a ser os executores da segunda fase do Proálcool, dando-lhe uma dimensão de grande escala dentro do chamado Modelo Energético Nacional. Posteriormente, esse desenvolvimento teve continuidade e foi intensificado com Lourival Carmo Monaco ocupando a Secretaria de Tecnologia Industrial do MIC. Outros grandes projetos da

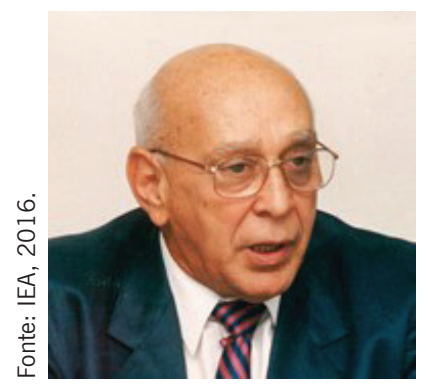

Figura 21: José Israel Vargas. 
área de energia da Comissão Nacional de Energia eram a exploração do petróleo da bacia de Campos, a construção das hidrelétricas (Itaipu e outras) e a construção das usinas nucleares (Angra). Os governos Geisel e Figueiredo ficariam marcados pela ênfase na questão energética.

Associação Brasileira de Reforma Agrária (ABRA) realiza a reunião Proálcool: fórum dos não consultados A Associação Brasileira de Reforma Agrária (ABRA), então presidida por Carlos Lorena, realizou em 1979 uma reunião em sua sede em Campinas para debater o Proálcool “à luz dos interesses dos trabalhadores”. Nessa reunião fizeram exposições José Goldemberg, José Francisco da Silva, Jacó Bittar, Maria da Conceição Tavares, Rogério Cezar de Cerqueira Leite, Luís Carlos Guedes Pinto, José A. Lutzemberger e Irma Passoni $1^{13}$. Eventos como esse, questionando o impacto social da expansão da produção de etanol e a repercussão das críticas de alguns estudiosos como Fernando Homem de Mello e Eduardo Gianetti da Fonseca da FEA/USP sobre a viabilidade econômica do etanol, induziram estudos mais aprofundados e medidas públicas que reforçaram a sustentabilidade da bioenergia da cana.

\section{Criação da empresa Fermentec}

O ano de 1979 também testemunhou a criação da empresa Fermentec por Henrique Vianna de Amorim (Figura 22), então professor da ESALQ/USP. Especializada em fornecer tecnologia de fermentação ao setor sucroalcooleiro, a Fermentec foi uma das responsáveis pelo aumento de rendimento da fermentação nas usinas do setor.

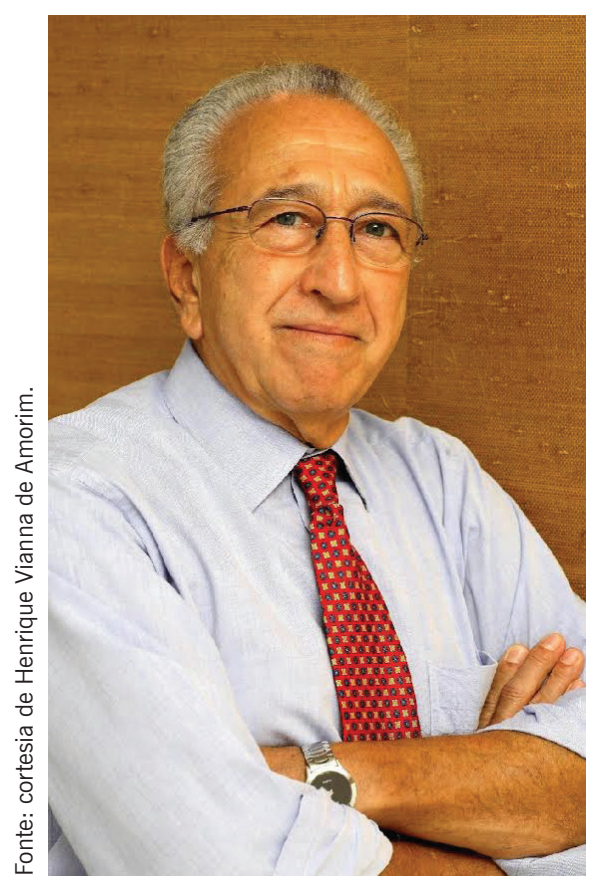

Figura 22: Henrique Vianna de Amorim.

\section{5-1983: a evolução da tecnologia industrial da produção de álcool}

No início do Proálcool, como o parque industrial compunha-se de usinas de açúcar, a solução inicial adotada foi o uso do melaço - resíduo da produção de açúcar - para a produção do etanol, o que atendeu às primeiras demandas do produto.

13 Mais sobre o debate da ABRA em: $<$ http://docvirt.com/docreader.net/DocReader.aspx?bib=hemerolt\&pagfis=8289\&pesq=\&esrc=s $>$. 
Com o crescimento do consumo, as usinas foram solicitadas a produzir mais etanol do que se poderia obter do melaço, adicionando-se então a este o caldo, que progressivamente foi aumentando no teor da mistura.

A elevação do consumo de etanol gerou, no fim da década de 1970 e início da de 1980, uma nova solução industrial: a usina dedicada de etanol, na época denominada "destilaria autônoma", concebida, projetada e implantada exclusivamente para a produção de etanol, utilizando o bagaço como fonte de energia gerada exclusivamente para uso nos processos internos.

Esse salto tecnológico se deu como resultado de esforços na sua quase totalidade nacionais, evidentemente considerando-se o estado da arte internacional como referência, a partir do qual se desenvolveram: uma nova concepção de planta industrial, dos seus processos e engenharia básica; novos fluxos, balanços de massa e de energia; detalhamento e novos equipamentos, que no seu todo constituíram a "usina de etanol". Essa foi a primeira inovação de ruptura promovida pelos vários agentes atuantes no setor sucroenergético do Brasil.

Essa solução foi evoluindo rapidamente nos primeiros anos da década de 1980, quando então foi realizado um seminário para apresentar uma visão geral da tecnologia industrial disponível em avançado estágio de desenvolvimento no Brasil.

\section{A Comissão Executiva Nacional do Álcool (CENAL) e a Secretaria de Tecnologia Industrial (STI),} ambas do MIC, realizaram em agosto de 1984, em Campinas (SP), o I Seminário de Tecnologia Industrial de Produção de Álcool, para o qual foram convidadas a indústria de equipamentos e as demais empresas fornecedoras da planta industrial e especialistas das universidades, com a missão de apresentar o estágio tecnológico dos seus fornecimentos e os próximos lançamentos a serem disponibilizados ao mercado. À CENAL/STI coube traçar um panorama geral do estado da arte e as tecnologias emergentes de maior impacto a serem utilizadas na usina de etanol.

O estágio avançado do desenvolvimento tecnológico da época pode ser verificado pela relação dos trabalhos apresentados no simpósio, listados no Quadro 1 com seus autores e as respectivas empresas. 
Quadro 1: Trabalhos apresentados no I Seminário de Tecnologia Industrial de Produção de Álcool (Campinas, 1984)

\begin{tabular}{|c|c|}
\hline 1. A extensão da safra canavieira: a análise e recomendações de políticas & $\begin{array}{l}\text { Prof. Bruce B. Johnson } \\
\text { Carlos Alberto Fenerich } \\
\text { Roland Fischmann } \\
\text { Instituto de Administração/FEA/USP }\end{array}$ \\
\hline $\begin{array}{l}\text { 2. Cana energética: avaliação do potencial de biomassa para a produção de } \\
\text { álcool }\end{array}$ & $\begin{array}{l}\text { Hasime Tokeshi } \\
\text { Escola Superior de Agricultura "Luiz de Queiroz" - ESALQ/USP }\end{array}$ \\
\hline $\begin{array}{l}\text { 3. Aumento da produção de álcool em função do pagamento de cana pelo } \\
\text { teor de sacarose }\end{array}$ & Antonio Celso Sturion IAA/Planalsucar \\
\hline 4. Sistema integrado de produção de álcool & $\begin{array}{l}\text { Dagoberto Núñez Marín } \\
\text { Antonio Pedro Lourenço } \\
\text { Antonio Carlos de Castro } \\
\text { Carlos Reynals Mourgues } \\
\text { Zanini S/A Equipamentos Pesados }\end{array}$ \\
\hline 5. Reduger "Sinopse" & $\begin{array}{l}\text { José Henrique de Paula Eduardo } \\
\text { Augusto Ivan Basualto Diaz } \\
\text { Conger S/A - Equipamentos e Processos }\end{array}$ \\
\hline $\begin{array}{l}\text { 6. Novas tecnologias de produção de álcool com redução do volume de } \\
\text { vinhaça }\end{array}$ & $\begin{array}{l}\text { Relatório do Grupo de Trabalho/CENAL-STI } \\
\text { Lourival Carmo Monaco } \\
\text { José Carlos Teixeira da Silva } \\
\text { Aluisio de Carvalho Guidi } \\
\text { Reginaldo Barroso de Rezende } \\
\text { Hermas Amaral Germek } \\
\text { Arnaldo Antonio Rodella }\end{array}$ \\
\hline $\begin{array}{l}\text { 7. Padronização da metodologia de análise no processo de produção de } \\
\text { álcool }\end{array}$ & $\begin{array}{l}\text { Carlos Ebeling } \\
\text { Proquip S/A Projetos e Engenharia Industrial }\end{array}$ \\
\hline 8. Controle integrado de destilaria de álcool & $\begin{array}{l}\text { Sistema de supervisão e controle ML-CD8490 } \\
\text { José de Almeida Telles Filho } \\
\text { Microlab S.A }\end{array}$ \\
\hline 9. Controle automático digital no processo de produção de álcool & $\begin{array}{l}\text { Dyonísio Garcia Pinatti - Destilaria Água Limpa } \\
\text { Carlos Roberto Libone - Smar Eqpts. Ind. Ltda } \\
\text { José A. Teles Filho - Microlab S/A } \\
\text { Euclides Robert Filho - Controle e Automação Digital Ltda. (CAD) } \\
\text { Affonso Silva Telles - Scientia Engenharia de Sistemas Ltda. }\end{array}$ \\
\hline 10. Tecnologias atuais da Dedini na Produção de álcool & $\begin{array}{l}\text { José Luiz Olivério } \\
\text { M. Dedini S/A Participações }\end{array}$ \\
\hline $\begin{array}{l}\text { 11. Perspectivas futuras da tecnologia de produção de álcool e seus possíveis } \\
\text { impactos }\end{array}$ & $\begin{array}{l}\text { Reynaldo Dias de Moraes e Silva - STI e ATEAI - Engenharia } \\
\text { Agroindustrial Ltda. }\end{array}$ \\
\hline
\end{tabular}


O texto a seguir, do então ministro João Camilo Penna (1983), pode ser entendido como uma avaliação geral do desenvolvimento da tecnologia industrial nesses primeiros anos de Proálcool.

Com base exclusivamente em esforços e técnicas nacionais, foi desenvolvido, em apenas oito anos, de 1975 a 1983 , um vasto elenco de conhecimento e experiências em todas as fases de produção de matérias-primas, processos de fabricação e do uso do álcool, com completo domínio tecnológico de todas essas etapas, em áreas como o desenvolvimento de novas variedades de cana-de-açúcar; o aproveitamento de subprodutos; projetos de máquinas e equipamentos agrícolas e industriais; e engenharia de motores; o aperfeiçoamento de materiais construtivos; o controle de emissões e consumo de combustíveis; as aplicações na alcoolquímica; e desenvolvimentos em setores de tecnologia de ponta, como a engenharia genética e o controle de processos por computadores, cujas contribuições certamente transcenderão os campos diretamente ligados ao Proálcool.

Face a esses esforços, o Brasil dispõe hoje de um parque industrial altamente capacitado e competitivo, a níveis internacionais, no setor de equipamentos para a produção de álcool.

Os temas discutidos e as tecnologias apresentadas são bastante avançadas; várias destas ainda permanecem competitivas e são utilizadas até hoje, trinta anos após o seminário de 1984. O processo Dedini Hidrólise Rápida (DHR) de produção de etanol a partir do bagaço foi também citado no seminário na sua configuração inicial, intitulando-se na época Projeto Acid Catalysed Organosolv Saccharification (ACOS) e sendo apresentado como um processo em desenvolvimento pela Dedini (Silva, 1984). O texto apresenta uma integração do DHR com a usina tradicional, ou seja, o etanol de segunda geração integrado ao de primeira geração. Nesse caso, a usina é projetada para máxima sobra de bagaço, a matéria-prima do etanol 2G. O texto destaca que o projeto se encontrava em fase de laboratório e que uma planta-piloto estava sendo engenheirada.

Alguns temas tratados nesse primeiro seminário ainda são objeto de discussão, estudo, investigação e/ou desenvolvimento. Entre eles: análise e impactos da extensão da safra canavieira com a recomendação das políticas indutoras; a cana energética e seu potencial de biomassa para a produção de etanol; o aumento da produção de álcool em função do pagamento da cana pelo teor de sacarose; a concepção sistêmica dos processos de produção de álcool visando atingir diferentes objetivos: máxima produção de álcool, máxima produção de energia, mínimo investimento, máxima produtividade industrial etc.; diferentes tecnologias de concentração de vinhaça e seus equipamentos: uso de evaporadores, fermentação de maior teor alcoólico, uso de mosto concentrado, integração fermentação-destilação; processos alternativos de fermentação: batelada, contínua, de dorna única, com recirculação de vinhaça, limitada pela pressão osmótica, limitada pelo teor alcoólico, fermentação com leveduras floculantes, fermentação sem reciclo de leveduras (sem Melle-Boinot), fermentação-destilação integradas, fermentação extrativa a vácuo; uso de membranas (osmose inversa) na 
separação do etanol durante o processo de fermentação; sistema de automação da usina integrando sub sistemas dos diferentes setores no conceito SDCD envolvendo o controle de processos; famílias de caldeiras com fornalhas altas revestidas de "paredes d'água" de tubos membranados com utilização de pré e superaquecedores e economizadores de ar conjugados e diferentes sistemas de combustão com automação a nível da operação automática, com capacidades, pressões, temperaturas e eficiência energética elevadas; evaporadores de película tipo falling film.

Alguns temas foram retomados somente a partir de 2002/2003 e outros ainda mais recentemente. O motivo é que o setor sucroenergético teve expansão acelerada até metade dos anos 1980, quando se atingiu um volume de produção de etanol de cerca de 12 bilhões de litros por ano, que permaneceu estagnada até a safra 2002/2003. Sem a presença de um mercado demandante de etanol, a tecnologia também se estabilizou, sendo promovidas somente inovações incrementais. A retomada do crescimento a partir de 2003 criou o mercado que possibilitou à indústria de bens de capital investir no desenvolvimento de novos processos e novos equipamentos.

\section{9-1987: avançam as pesquisas do IPT sobre o etanol}

Projetos importantes desenvolvidos no IPT incluem:

- Química: Microusina de etanol; desidratação de álcool etílico para produção de etileno; reforma com vapor de metanol para produção de hidrogênio; produção de catalisadores em escala piloto; produção de álcool etílico por fermentação alcoólica contínua. Ressaltem-se aqui os trabalhos ${ }^{14}$ de Walter Borzani, engenheiro químico da Escola Politécnica da USP, os quais tiveram fundamental papel na introdução e na conceituação da disciplina de biotecnologia industrial. Borzani teve importante atuação no desenvolvimento da pesquisa na área de fermentação, sendo o primeiro a defender e aplicar o conceito de fermentação contínua para a fermentação alcoólica.

- Engenharia mecânica: Em 1979 foi construído no IPT o novo prédio do Laboratório de Motores. Os principais projetos desenvolvidos pelo grupo do Laboratório de Motores, o qual chegou a contar com treze engenheiros sob a liderança dos professores da Escola Politécnica Nedo Eston de Eston e Francisco Nigro, assim como os respectivos clientes, foram:

14 Segundo Amorim (2005), Borzani publicou mais de uma centena de trabalhos sobre as novas tecnologias da indústria açucareira. 
- 1980, CELPA: Etanol nebulizado no ar de admissão de motor diesel para grupo gerador.

- 1981/1983, CESP: Metanol emulsificado em diesel; metanol com "ponto quente".

- 1980, EMPLASA, EMTU: Acompanhamento da operação de linha de ônibus a álcool aditivado (Mercedes-Benz; Viação Urubupungá).

- 1982/1985, CESP: Uso de metanol por dupla injeção em motores de locomotivas, solução complexa, mas mais eficiente que as demais para motores de grande cilindrada unitária (90\% metanol, 10\% diesel); desenvolvimento do sistema, adaptações na máquina e testes de desempenho e emissões em locomotiva GE U6C; manual de modificação das máquinas.

- 1984/1985, PROMOCET: Emissões (regulamentadas e aldeídos) de motor diesel operando com álcool aditivado e de motor Otto a etanol.

- 1986, CESP: Uso de misturas etanol, metanol e gasolina em motores Otto a etanol; ensaios em dinamômetro e campo. Os resultados anteciparam e serviram de base para o estabelecimento da metanol-etanol-gasolina (MEG), que permitiu abastecer a frota a álcool por ocasião do desabastecimento de etanol em 1989.

Durante uma década, iniciada no ano de 1987, as pesquisas e desenvolvimentos sobre o uso de etanol em motores foram praticamente interrompidos, em face da nova realidade de produção limitada de etanol e do desinteresse governamental em incentivar o uso do biocombustível. O grupo de motores do IPT foi reduzido à terça parte, com redirecionamento das pesquisas para o uso de gás natural e dispersão de boa parte das competências que haviam sido estabelecidas.

\section{Década de 1980}

\section{0: Amorim, da ESALQ/USP, desenvolve com a empresa Zanini o Sistema Zanifloc}

Zanifloc é um processo com leveduras floculantes objetivando a substituição de centrífugas. Henrique Vianna de Amorim, então na ESALQ/USP, havia desenvolvido no fim dos anos 1970 uma levedura floculante para a empresa Hoechst, detentora da patente (Amorim, 2005). 


\section{2: Lamartine Navarro Júnior cria a Coleção Sopral}

A Sociedade de Produtores de Açúcar e de Álcool (Sopral) criou em 1982 a Coleção Sopral com o objetivo de publicar informações relevantes sobre a produção e uso de álcool combustível de cana-de-açúcar no Brasil. Essa coleção contou com os seguintes livros:

- Avaliação do carro a álcool, 1982.

- Avaliação econômica e social do Proálcool, 1982.

- Avaliação de caminhões e tratores a álcool, 1983.

- Avaliação do bagaço de cana-de-açúcar, 1983.

- O Proálcool vale?, 1984.

- Proálcool: despesas e receitas a nível de governo, 1985.

- V Encontro Nacional dos Produtores de Álcool - V Econálcool, 1985.

- Aspectos econômicos, jurídicos e sociais da reforma agrária, 1985.

- Avaliação do proálcool e suas perspectivas, 1986.

- Avaliação do vinhoto como substituto do óleo diesel e outros usos, 1986.

- VI Encontro Nacional dos Produtores de Álcool - VI Econálcool, 1986.

- O Proálcool em fase de queda dos preços do petróleo, 1986.

- Reflexos da queda dos preços do petróleo na economia nacional e internacional, 1986.

- O álcool no contexto dos combustíveis líquidos, 1987.

\section{3: a alcoolquímica ganha destaque}

Romeu Botto Dantas, renomado técnico da Universidade Federal de Pernambuco (UFPE), ajudou a promover a alcoolquímica (Dantas, 1988). Destaque-se, também, o pioneirismo empresarial de 
Kurt Politzer, que, por meio da empresa Indústrias Químicas Taubaté (IQT), desenvolveu inúmeros processos da alcoolquímica no âmbito industrial.

\section{5: o Simpósio Internacional Copersucar - Açúcar e Álcool se realiza em comemoração do décimo aniversário do Proálcool}

Em julho de 1985, a Copersucar realizou em São Paulo o primeiro encontro mundial a discutir, simultaneamente, assuntos ligados ao açúcar e ao álcool. O evento teve grande repercussão, promovendo uma importante discussão sobre a dualidade açúcar-etanol, derivados da mesma cana-de-açúcar. Além disso, tornou-se um painel que propiciou aquele que, provavelmente, foi o primeiro debate sobre a internacionalização do etanol como substituto dos derivados de petróleo, notadamente a gasolina. O simpósio teve 549 participantes de 32 países e recebeu grande destaque na imprensa nacional e internacional.

O encontro teve palestrantes convidados das entidades mais representativas do governo, além de associações e especialistas do Brasil, Austrália, África do Sul, Cuba, Estados Unidos, Comunidade Econômica Europeia, México, países do Caribe, Japão, Inglaterra, entre outros. Os temas abordados foram políticas, mercado, avaliação energética, internacionalização, aspectos econômicos, aspectos sociais, aspectos ambientais, logística, uso automotivo, alcoolquímica, debate food $\times$ fuel e tecnologia.

Quanto à tecnologia, a palestra, destacando o papel da indústria de bens de capital no Proálcool (Giannetti, 1985), apresentou máquinas, equipamentos e processos representativos do estado da técnica de produção de etanol no Brasil, com três objetivos: redução do custo do investimento, aumento da produtividade e aumento do rendimento energético.

O trabalho destaca a evolução ocorrida em dez anos de Proálcool, decorrente do desenvolvimento tecnológico do setor, informando os desempenhos representativos das melhores práticas nas usinas.

Todas essas tecnologias são integradas na concepção de "unidades autônomas" exclusivas para a produção de álcool, na época denominadas "destilarias autônomas de álcool” e hoje mais corretamente denominadas "usinas de etanol”, sendo apresentadas três soluções básicas: usinas de máxima produção de etanol, usinas de máxima produção de energia e usinas de mínimo investimento. 
A Tabela 1 registra as melhores práticas informadas na palestra (1985), comparando-as com os equivalentes desempenhos do início do Proálcool (1975) e com as melhores práticas atuais (2012/2013).

\section{Tabela 1: Resultados da evolução tecnológica industrial}

\begin{tabular}{|c|c|c|c|c|}
\hline Descrição & Início & 1985 & Atual & Observações \\
\hline \multicolumn{5}{|l|}{ 1. Aumento da capacidade de produção } \\
\hline Moenda: $6 \times 78^{\prime \prime}-\mathrm{t}$ cana/dia & 5.500 & 10.000 & 15.000 & Seis ternos + facas + desfibrador \\
\hline Tempo de fermentação: horas & 24 & & 6 a 8 & Fermentação tradicional - batelada/contínua \\
\hline Teor alcoólico no vinho: ${ }^{\circ} \mathrm{GL}$ & 6 & & 12 a $16\left(^{*}\right)$ & ${ }^{*}$ uso Ecoferm - Dedini/Fermentec \\
\hline \multicolumn{5}{|l|}{ 2. Aumento das eficiências } \\
\hline Extração do caldo: \% & 93,0 & 96 & $97(98)$ & Facas + desfibrador + Seis ternos (ou difusor) \\
\hline Rendimento fermentativo: $\%$ & 80,0 & 91 & 91,5 & Relação estequiométrica \\
\hline Recuperação destilação: \% & 98,0 & 99,0 & 99,7 & \\
\hline \multicolumn{5}{|l|}{ 3. Otimização do consumo energético } \\
\hline Consumo de vapor açúcar/etanol & 600 & & 320 & $\mathrm{~kg}$ vapor/t cana moída \\
\hline Consumo vapor etanol anidro & 5 & & 2 & $\mathrm{~kg}$ vapor/litro etanol anidro \\
\hline Pressão das caldeiras - bar & 21 & 42 & 100 a 120 & \\
\hline Temperatura vapor - Celsius & 300 & 400 & 540 & \\
\hline Eficiência energética caldeira: \% & 66 & 86 & 89 & \\
\hline Biometano da vinhaça & Nulo & 0,1 & 0,1 & $\mathrm{Nm}^{3}$ biometano/litro etanol \\
\hline \multicolumn{5}{|l|}{ 4. Parâmetros globais } \\
\hline Sobra bagaço para energia: \% & Nulo & até 70 & Até 78 & $100 \%$ produção etanol \\
\hline Venda de energia para rede & Compra & & Sim & Cana padrão: $12,5 \%$ fibra \\
\hline Vinhaça produzida & 15 & $<1$ & $<1$ & Litro vinhaça/litro etanol \\
\hline Biofertilizante sólido: kg/t cana & Nulo & & 50 a $60\left(^{*}\right)$ & $\left(^{*}\right)$ BIOFOM \\
\hline Produção biodiesel integrada & Não & & $\operatorname{Sim}\left({ }^{*}\right)$ & $\left(^{*}\right)$ Usina Barralcool - Dedini/2006 \\
\hline Uso energético da palha da cana & Não & & Inicial & Em início de utilização \\
\hline Energia elétrica para venda & Nula & & Até 90 & kW/t cana \\
\hline Consumo água: litros/l etanol & 187 & 43 & Nulo/exportação & Captação águas mananciais \\
\hline Produção etanol: litros/t cana & 66 & & 87 & \\
\hline
\end{tabular}

Fonte: Olivério, 2006 apud CNI, 2012. 
Conforme se verifica na Tabela 1, ocorreram expressivas evoluções nos desempenhos das usinas no estado da arte em decorrência da tecnologia desenvolvida ao longo dos anos, o que foi possível com o acentuado crescimento do processamento da cana (de 68 milhões para 223 milhões de toneladas de cana por safra) e da produção de etanol (de 550 milhões para 12 bilhões de litros de etanol por safra).

Destaque-se a apresentação de inúmeras inovações que, em grande parte, estão em uso hoje ou ainda são desafios tecnológicos do setor, como: os desfibradores verticais; a queda Donelly; a fermentação contínua; a fermentação-destilação Biostil, que possibilita a concentração da vinhaça; a produção de biogás/ biometano a partir da biodigestão anaeróbia da vinhaça; a visão sistêmica aplicada à concepção, engenharia básica e detalhamento da planta completa, em que se considera a usina como um único produto, cujo conjunto possibilita a obtenção de resultados pré-definidos como "máxima produção de álcool" e "máxima produção de energia"; a industrialização do bagaço (transformando-o em produto); a industrialização da cana integral, com palhas e pontas, sem queima; e a produção de etanol celulósico a partir do bagaço e da palha.

\section{5: pesquisas pioneiras sobre a secagem do bagaço de cana no Brasil}

O bagaço de cana é o combustível usado pelas usinas do Brasil e de todo o mundo. Da forma como é obtido, seja pela moagem ou por meio da tecnologia de difusão, se encontra úmido (cerca de 50\% de umidade, base úmida ${ }^{15}$. E é dessa forma, úmido, que é colocado nas caldeiras para ser queimado. No entanto, sabe-se tecnicamente que se essa umidade for reduzida pode-se aumentar a temperatura da combustão e, consequentemente, sua eficiência. Foi com base nessa premissa que Sílvia Azucena Nebra desenvolveu, na Faculdade de Engenharia Mecânica da Unicamp, um secador pneumático para secagem de bagaço (Nebra, 1985).

\section{Meados da década de 1980: fim do Proálcool}

Com o fim do regime militar e o começo da Nova República, o Proálcool deixou formalmente de existir como programa governamental de incentivo à produção de álcool combustível.

15 Mais informações sobre a caracterização de bagaço podem ser encontradas em Cortez et al. (2008). 
No entanto, vale salientar que as políticas de apoio à produção de cana-de-açúcar e de uso de álcool combustível foram continuadas, haja vista o aumento na produção de veículos a álcool pela indústria automobilística.

\section{Alguns dos principais impactos técnicos que representaram impasses iniciais ao desenvolvimento do Proálcool}

\section{Escala de produção}

No início do Proálcool, o governo propôs que a destilaria padrão produziria $120 \mathrm{mil} \mathrm{litros} \mathrm{de} \mathrm{álcool/dia.}$ Esse porte, hoje considerado pequeno, foi contestado por vários pesquisadores. Romeu Corsini, da EESC/USP, propôs um modelo baseado em "minidestilarias" capazes de produzir 20 mil litros de etanol/dia e que poderia, em teoria, tornar-se uma versão "mais socializada" do programa de etanol (Mini-usinas de álcool integradas - MUAI, Corsini, 1992). Na época, surgiram várias empresas vendendo unidades de até $1 \mathrm{mil}$ litros/dia, mas a pequena escala não conseguiu atingir os níveis de produtividade, qualidade e economicidade das usinas maiores, especialmente dada a enorme escala do mercado de combustíveis líquidos. Posteriormente, Enrique Ortega, da Faculdade de Engenharia de Alimentos da Unicamp, trabalhou no mesmo conceito de produção em pequena escala.

Nesse sentido, havia, e há até hoje, controvérsia sobre a escala de produção. O tamanho inicialmente escolhido (120 mil litros de álcool/dia) pode ser considerado hoje uma usina de menor porte. A ideia de Corsini era favorecer as miniusinas (20 mil litros/dia), mas havia quem defendesse as microusinas (1 mil a 5 mil litros de álcool/dia).

Contudo, ao longo desses quarenta anos após o início do Proálcool, pode-se dizer que os custos de produção decrescem significamente com o aumento da escala da usina. Isso pode se visualizado na Figura 24. Por outro lado, o porte das usinas ainda é limitado pelos custos crescentes decorrentes do transporte da cana às usinas. Nesse sentido, é importante notar a significativa importância do custo de transporte da cana no custo final do álcool, cerca de 15\% a 20\%, segundo Oscar Braunbeck, do Laboratório Nacional de Ciência e Tecnologia do Bioetanol (CTBE). 
Corte manual e transporte em cangalha

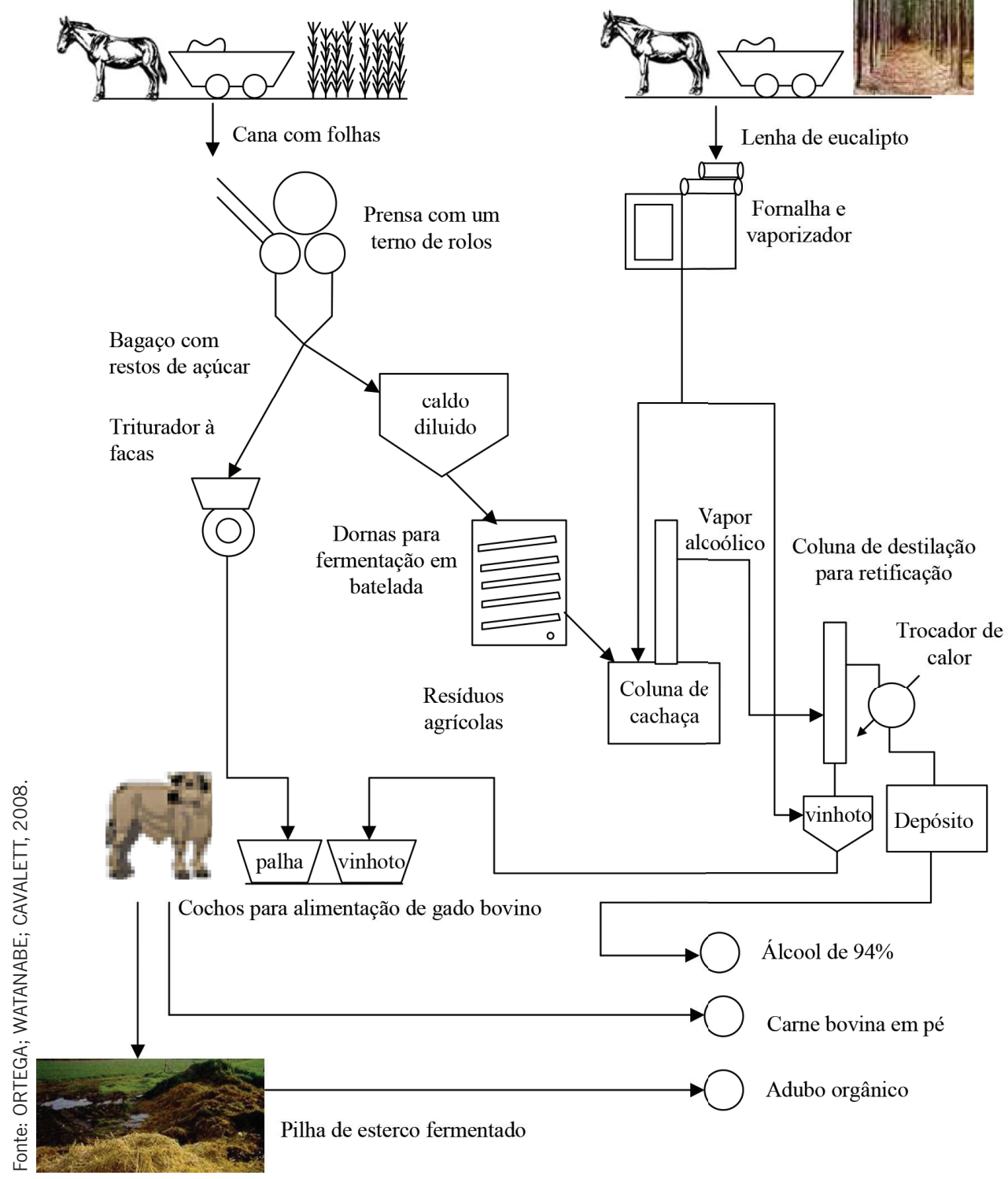

Figura 23: Fluxograma de uma miniusina de álcool, com difusor, fazendo parte de um Sistema Integrado de Produção de Alimentos e Energia (SIPEA). 
Assim, hoje, as usinas de açúcar e álcool, instaladas no centro-sul do Brasil, variam de tamanho em uma faixa de 500 mil a até 8 milhões de litros de álcool por dia.

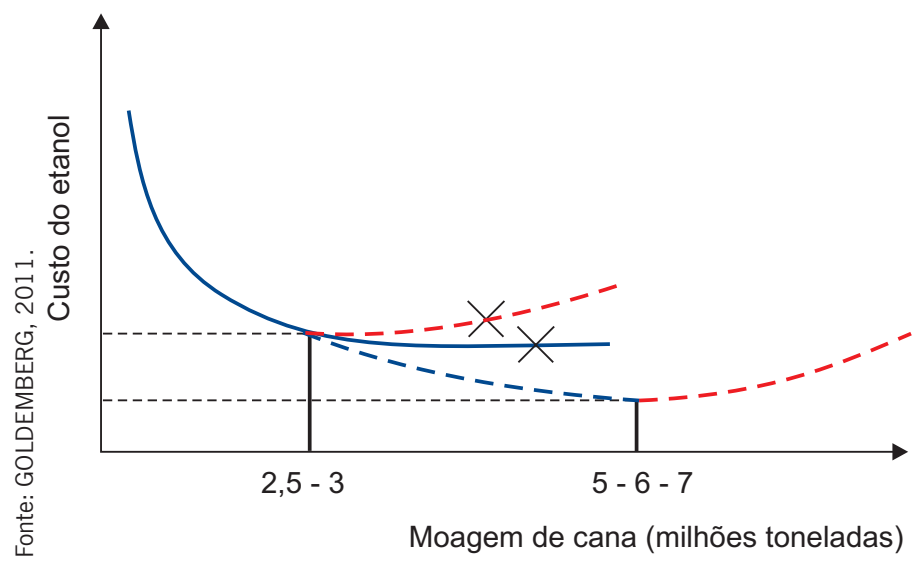

Figura 24: Custo de produção de etanol em função do tamanho da destilaria.

Note-se que, além da escala, há outros fatores que devem ser considerados na produtividade e rentabilidade da produção de etanol. A Figura 25 mostra que tanto a produtividade da cana-de-açúcar como os açúcares totais recuperáveis (ATR) variam consideravelmente nas usinas brasileiras (CTC, 2007).

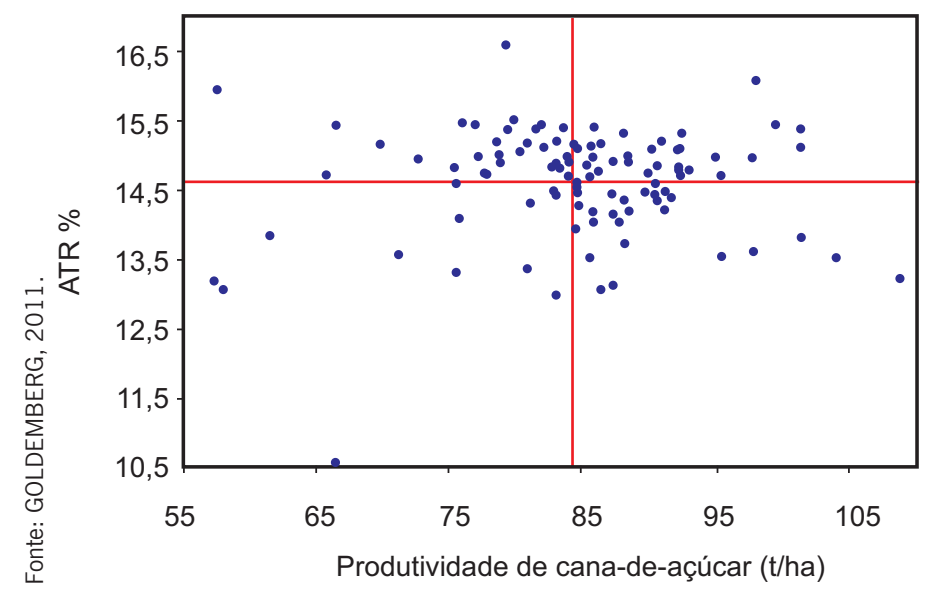

Figura 25: Resultados agronômicos (produtividade da cana e ATR) das usinas brasileiras. 


\section{Uso de outras matérias-primas}

Considerou-se no início do Proálcool a possibilidade de utilizar outras matérias-primas na produção de etanol. Os documentos do Proálcool mencionavam, entre outras, a mandioca e o sorgo sacarino. Essa ideia, aliás, guarda semelhanças com o que ocorre hoje com o biodiesel, para cuja produção se pretende incentivar outras culturas, além da soja, descentralizar a produção e dar acesso ao pequeno produtor.

Vale menção a iniciativa da Embrapa, que chegou a implantar em Jundiaí (SP) um modelo de pequena escala, usando difusores em vez de moendas e operando com sorgo sacarino e cana-de-açúcar (Teixeira et al., 1999). Um dos méritos desse projeto foi a tentativa de prolongar a safra da cana usando uma outra matéria-prima, no caso o sorgo sacarino. Essa estratégia veio a ser utilizada mais recentemente, com a comercialização de sementes de sorgo junto a produtores de cana-de-açúcar ${ }^{16}$.

Outro projeto de destaque foi o liderado pela Petrobras, com tecnologia desenvolvida pelo Instituto Nacional de Tecnologia, na cidade de Curvelo (MG), que implantou uma destilaria de álcool de 60 mil litros/dia a partir da mandioca ${ }^{17}$. $\mathrm{O}$ fracasso da iniciativa deveu-se especialmente à dificuldade de suprimento de matéria-prima (Castro e Swartzman, 2008). Outra tentativa em maior escala foi desenvolvida em 1985 em Sinop (MT), que também fracassou pelos mesmos motivos ${ }^{18}$.

Em 1978, o grupo de Ulf Schuchardt, da Unicamp, iniciou seus estudos de hidrogenólise de biomassas. Foram obtidos bio-óleos de elevada qualidade a partir de bagaço de cana. Devido a esse sucesso, a FINEP financiou a construção de um reator contínuo de hidrogenólise de biomassas, que foi principalmente utilizado para a liquefação da lignina da planta de demonstração da Coalbra. Esse reator foi operado durante cerca de cinco anos e forneceu bio-óleos estáveis com mais de $60 \%$ de rendimento.

\section{Uso da vinhaça como fertilizante (fertirrigação)}

Também nos primeiros anos do Proálcool, a vinhaça, resíduo líquido da destilação do etanol, produzida na proporção de 10 a 14 litros de vinhaça por litro de etanol, era apontada como um grande problema ambiental.

16 Conforme <www.ceres.net/ceressementes/Produtos/Produtos-Sorgo-Sacarino.html $>$.

17 Conforme <www.Unicamp.br/Unicamp/ju/544/mandioca-gera-etanol-e-eletricidade $>$.

18 Conforme <http://economia.estadao.com.br/noticias/negocios,o-potencial-da-mandioca-para-fabricacao-de-etanol,20061020p1396>. 
O que fazer com tanta vinhaça, era a pergunta da época. Até então, era frequente o seu despejo em cursos d'água, fazendo-os sofrer com a alta carga orgânica desse resíduo.

No final dos anos 1970, o Centro de Tecnologia Promon desenvolveu um estudo multicliente e realizou seminários com avaliações das múltiplas tecnologias disponíveis para o processamento da vinhaça. Nesse período, Otávio Camargo, do Instituto Agronômico (IAC), realizou, com recursos do Banco Nacional de Desenvolvimento Econômico e Social (BNDES) para o Proálcool, extensos estudos para medir o impacto de longo prazo do uso da vinhaça sobre o solo (Camargo, Valadares e Girardi, 1983). Nadir Almeida da Glória (Figura 26), da ESALQ/USP, foi um dos pesquisadores que mais estudaram a aplicação de vinhaça no solo, a qual acabou por se tornar uma prática rotineira nas usinas (UDOP, 2015).

Posteriormente, o CTC desenvolveu ainda mais a fertirrigação (Figura 27), e hoje essa prática ajuda o setor a economizar quantidades significativas de potássio, elemento do qual a vinhaça é bastante rica (Copersucar, 1990). Muito do desenvolvimento da fertirrigação da vinhaça e uso da torta de filtro e seus impactos agronômicos deve-se à equipe do IAC, coordenada por Raffaella Rosseto. Destacam-se os trabalhos da Cetesb e da Unica, que, em parceria, elaboraram uma norma técnica definindo dosagens para a vinhaça dependendo do tipo de solo, e as pesquisas de Márcia Jostino Rossini Mutton, da Unesp/Jaboticabal. Uma série de decretos e resoluções governamentais nesses quarenta anos após a criação do Proálcool viriam a regulamentar a aplicação de vinhaça e outros efluentes no solo. Mais detalhes podem ser encontrados em Mutton et al. (2010) e Souza et al. (2015).

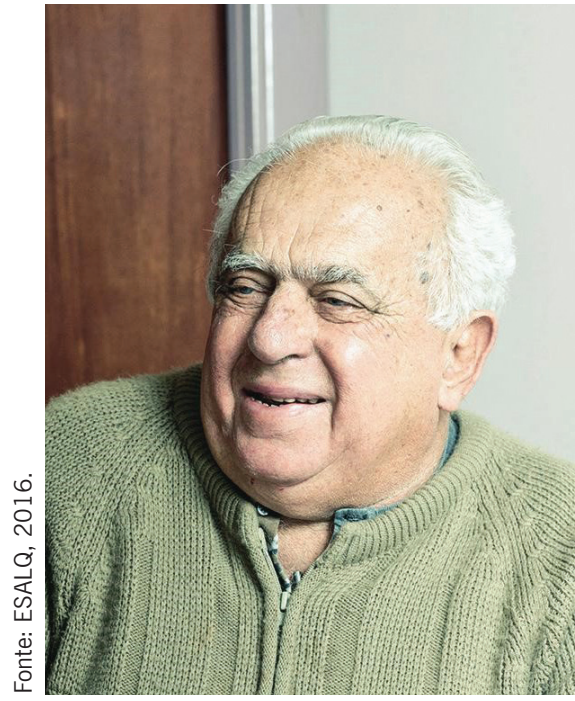

Figura 26: Nadir Almeida da Glória.

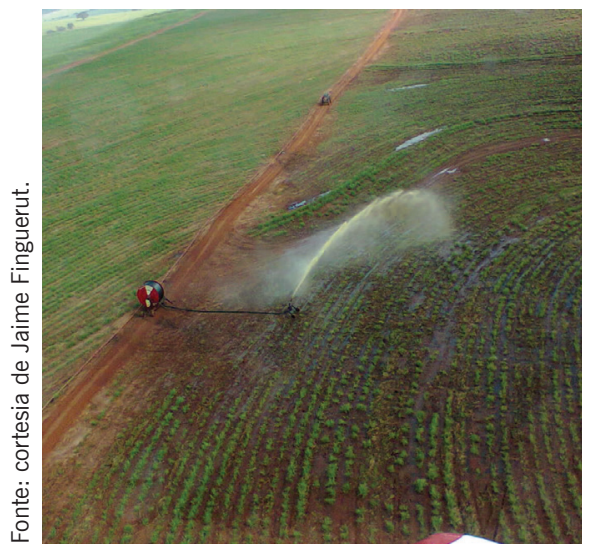

Figura 27: Fertirrigação com vinhaça. 


\section{A questão dos subsídios}

O Proálcool teve um período inicial (1975 até início dos anos 1980) marcado por investimentos subsidiados. Esses subsídios à formação do canavial e à implantação das usinas eram fornecidos, por meio de empréstimos, a juros muito baixos ou até negativos, dependendo da região onde o projeto iria ser implantado, visando permitir o seu desenvolvimento inicial. Na época houve críticas a esses subsídios, como as apresentadas por Amaral Gurgel, respeitado empresário nacional do setor automotivo.

No entanto, com a mudança de regime, de militar para civil-democrático, houve uma fase de liberalização que não permitia mais haver setores subsidiados na economia bastante debilitada pelas sucessivas crises. As variações consideráveis de preços do petróleo e do açúcar, além de crises econômicas e políticas na década de 1980, levaram à liberalização do setor. A partir desse período já não existia o Proálcool, entendido como um programa de incentivos do governo federal.

\section{Concentração da produção}

Inicialmente, era previsto também que o Proálcool ajudasse na redução das desigualdades regionais do país. Para tanto, eram dados incentivos à produção no Nordeste em relação ao Sudeste. Em 1975, a produção de cana-de-açúcar do Nordeste representava quase metade do total produzido no país (cerca de $100 \mathrm{mi-}$ lhões de toneladas).

No entanto, contrariamente ao que se desejava e provavelmente motivadas pela disponibilidade de terras aptas, mão de obra qualificada em todos os níveis e infraestrutura existente, as usinas foram instaladas em sua grande maioria nos estados da região Sudeste (Figura 28).

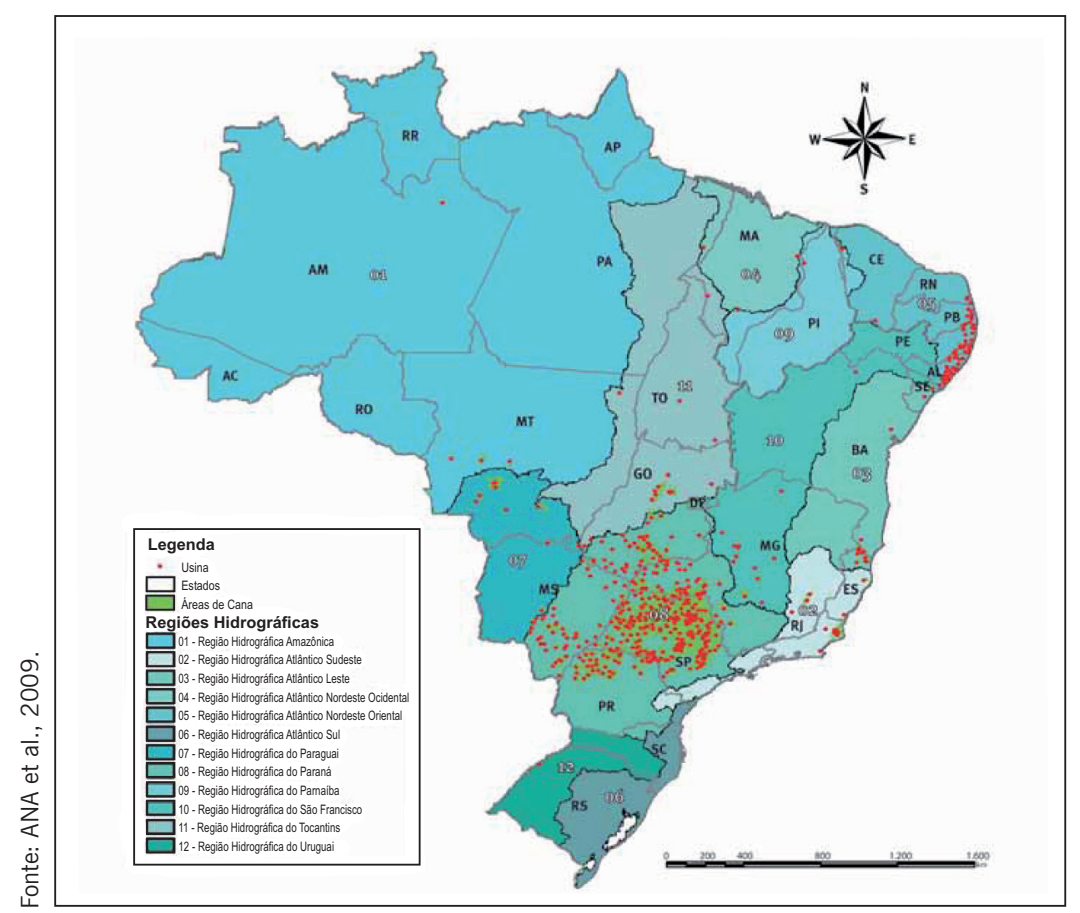

Figura 28: Localização das usinas no Brasil e no estado de São Paulo. 


\section{Estudos sobre termoconversão}

Até hoje não há consenso no mundo quanto ao processo que possibilita o melhor aproveitamento das fibras da biomassa. A questão que se coloca é se a rota bioquímica (hidrólise) é ou não mais vantajosa do que a rota termoquímica (combustão, gaseificação ou pirólise).

Os trabalhos experimentais com a termoconversão de biomassa (torrefação, pirólise, gaseificação e combustão) foram cronologicamente iniciados no Instituto de Pesquisas Tecnológicas (IPT), em São Paulo, na década de 1970, quando foi criado o laboratório de combustão. Recentemente, o IPT, sob a coordenação de Fernando Landgraff, chegou a elaborar um projeto de pirólise com posterior gaseificação, para viabilizar maiores escalas de produção.

Na Unicamp, três grupos se destacam na área de termoconversão: o primeiro é o de Carlos Luengo (Figura 29), do Instituto de Física Gleb Wataghin (IFGW), criador do Laboratório de Combustíveis Alternativos, que realiza pesquisas básicas dos processos de termoconversão de biomassa, sobretudo em pirólise e torrefação. O segundo, de Saul D'Ávila, na Faculdade de Engenharia Química (FEQ), pesquisou e formou quadros em gaseificação de biomassa, sobretudo nas décadas de 1970 e 1980. Um terceiro grupo se organiza na Faculdade de Engenharia Mecânica (FEM), com Caio Sanchez e Waldir Bizzo nas pesquisas de laboratório de combustão e gaseificação e Márcio Souza-Santos na área de modelagem da gaseificação.

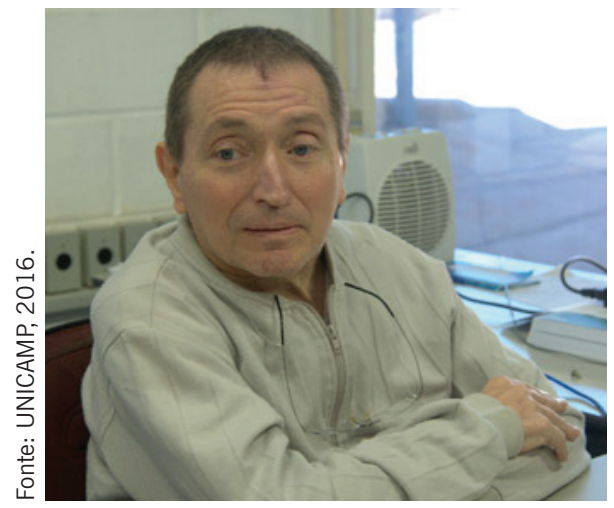

Figura 29: Carlos Luengo.

Na Unifei, em Itajubá, Electo Silva-Lora desenvolveu pesquisas em gaseificação de biomassa, principalmente de cana-de-açúcar, e criou o Núcleo de Excelência em Geração Termelétrica e Distribuída (NEST).

Muitos dos gaseificadores utilizados por esses grupos de pesquisa foram produzidos pela empresa Termoquip, instalada em Campinas, com os engenheiros Themístocles Rocha e Cláudio Moura. Vários dos gaseificadores utilizados pelos diferentes grupos de pesquisa em termoconversão foram construídos pela Termoquip. 
Outras pesquisas em gaseificação e cogeração foram desenvolvidas por José Luz Silveira, da Unesp Guaratinguetá.

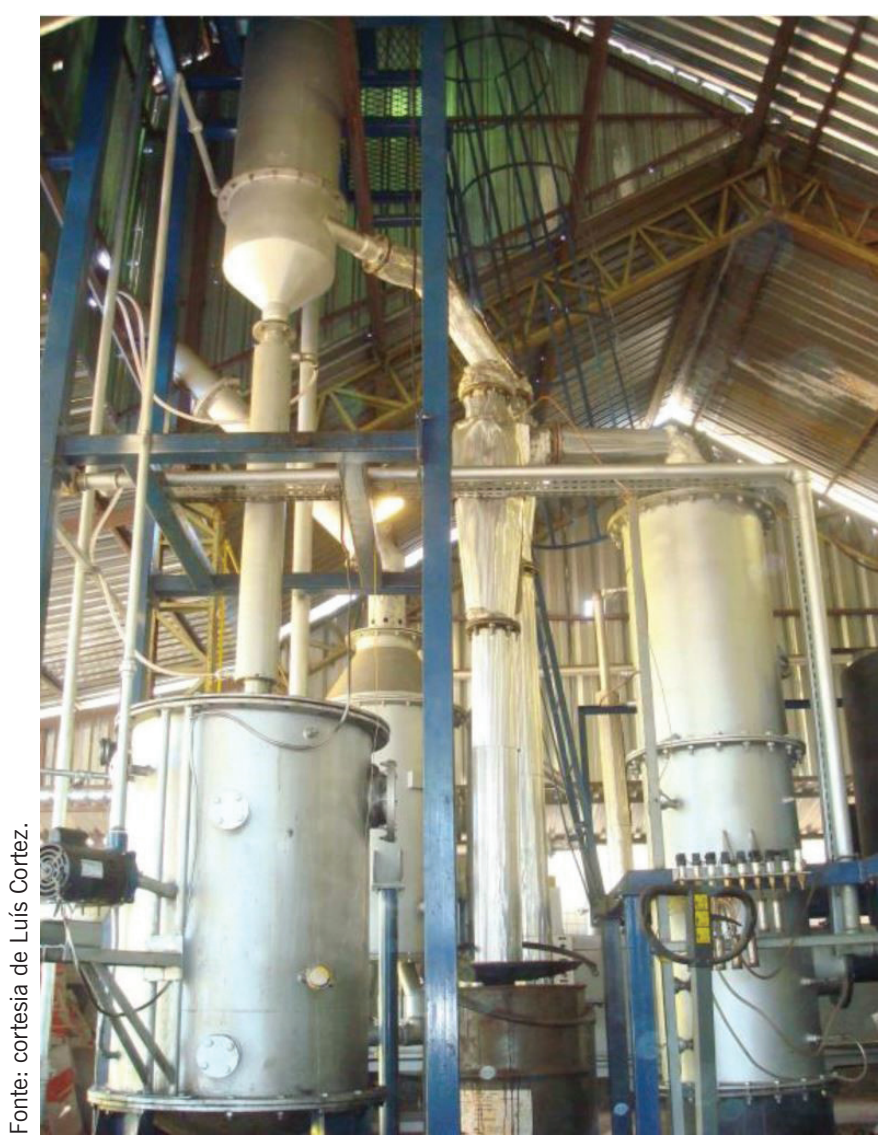

Figura 30: Planta-piloto de pirólise rápida da Unicamp. 